УДК 658.521

\title{
ЗАХИСТ ЦИФРОВОЇ ФОТОГРАФІЇ ЗА ДОПОМОГОЮ ЦИФРОВИХ ВОДЯНИХ ЗНАКІВ
}

\author{
( Т. А. Роїк, д.т.н., професор, О. Ю. Райченко, \\ магістрантка, НТУУ «КПІ», Київ, Україна
}

\begin{abstract}
В статье представлены основные преимущества и недостатки цифровых изображений, методы защиты цифровых фото, анализ их надежности и возможные альтернативы защиты авторских прав. Предложен новый вариант защиты цифровой фотографии на начальной стадии ее создания. Представлен пооперационный алгоритм создания цифровых водяных знаков для защиты цифровой фотографии.
\end{abstract}

In the article the main advantages and disadvantages of digital images, methods of protecting digital photos, analyzes their reliability and possible options to protect copyrighted digital photo have been presented. There were offered new options for protecting digital photography at early stage of its development. Phase algorithm of development a digital watermark for images protection have been shown.

\section{Постановка проблеми}

Створення фотографії, яка відповідає сучасним вимогам, обходиться дуже недешево і являє собою досить трудомісткий процес, часто пов'язаний із застосуванням передових сучасних технологій [1]. В той же час «правова надійність» охорони цифрових фотографій в Україні нині дуже невелика поряд з поширенням фотографічних робіт з використанням сучасної техніки, яке стає все більш розповсюдженим.

Цифрове фото дуже легко копіювати і поширювати поза авторським контролем. Поряд з очевидними перевагами цифрової фотографії: зручність використання, оперативність роботи, легкість виправлення-редагування існує один серйозний недолік, який не має відношення до творчості - цифрову фотографію дуже легко скопіювати або, простіше, «поцупити». Враховуючи, що при копіюванні цифрових зображень якість копії не погіршується в порівнянні з оригіналом, то очевидно, зникає остання перешкода на шляху фотопіратства. Досить передати кому-небудь файл або просто помістити фото в Інтернет, і ніяких гарантій, що фотографія не буде десь опублікована і хтось інший не буде одержувати за неї винагороду замість автора. Тому вихід один - захистити зображення від фальсифікації, плагіату, спотворення, підміни авторства тощо.

Виходячи з вищевикладеного тема дослідження захисту цифрової фотографії за допомогою цифрових водяних знаків $€$ актуальною, що пов'язано, насампе- 
ред, із потребою захистити авторське право на цифрове зображення. Окрім цього у зв'язку з інтенсивним розвитком та поширенням цифрових технологій і фотографічної техніки, які дозволяють за допомогою комп'ютера інтегрувати, обробляти і синхронно відтворювати різні типи мультимедійної інформації, питання захисту інформації, представленої в цифровому вигляді, $€$ надзвичайно актуальним і потребує виконання комплексу досліджень.

\section{Аналіз попередніх досліджень}

у багатьох публікаціях, зокрема, у роботі [1] наголошується на тому, що використання чужого цифрового зображення $€$ недопустимим у будь-яких цілях, а особливо у комерційних, без посилання на власника авторських прав на це зображення.

Автори робіт [2, 3], досліджуючи стеганографічні методи захисту цифрових зображень, доводять високу ступінь їх надійності, але водночас висловлюють думку, що жоден з методів захисту не дає стовідсоткової гарантії, тому для кращого результату радять поєднувати методи цифрової стеганографії з видимими цифровими водяними знаками чи електронним підписом.

В роботах $[4,5]$ автори детально пояснюють, як відбувається захист цифрової інформації в цілому, за яким принципом працюють стеганосистеми, що вирішують задачу захисту авторського права в зображеннях, як правильно підбирати для них ключі та як захистити об'єкт авторського права від піратства, що є важливим з точки зору обирання заходів захисту.

Аналіз напрацювань з розглядуваної теми показав, що питання захисту авторських прав на цифрове зображення постає дедалі гостро. Чим інтенсивніше розвивається ринок цифрових можливостей, тим частіше ми зустрічаємось 3 плагіатством та підміною авторства, незаконним використанням та привласненням чужої творчої праці, що свідчить про нагальну потребу досліджень в даному напрямі та створення нових методів захисту цифрової фотографії.

\section{Мета роботи}

Метою даної роботи $є$ аналітичне дослідження із захисту цифрової фотографії за допомогою цифрових водяних знаків і запропонування нового варіанту захисту цифрової фотографії на початковій стадії її створення.

\section{Результати досліджень}

Цифровий водяний знак (ЦВЗ) являє собою деяку інформацію, мітку, яка додається до цифрового об'єкта і може бути виявлена (витягнена) для висування прав на цей об'єкт [2]. Спеціальна інформація, яка утворює ЦВЗ (про час і місце його створення, про авторські права тощо) може бути розпізнана лише спеціальними програмними засобами та системами [3].

Основною вимогою до систем цифрових водяних знаків € стійкість цифрової мітки до різноманітних трансформацій файлу-носія (зміни формату, ущільнення, аналогового перетворення цифрових обробок) 
та до спроб її видалення третіми особами [3]. Іноді не менш важливою вимогою $€$ невидимість ЦВЗ.

Існуючі на сьогодні методи, що вирішують задачу захисту авторського права шляхом вбудовування ЦВЗ, розділяють на дві групи: група методів, які приховують інформацію в просторовій області зображення та методи, що вбудовують ЦВЗ в частотну область [4].

Основною частиною роботи, і найбільш вагомою, було проведення патентного пошуку за допомогою веб-ресурсів (http:// ep.espacenet. i http://www1.fips. ru), знайдено потрібні класи міжнародної класифікації стосовно створення ЦВЗ, розроблено регламент пошуку, який відображає предмет і зміст пошуку, мету (аналізувати методи створення ЦВЗ для захисту цифрового зображення), ретроспективність 10 років, країни Росія, США, Японія, Китай, Корея, Німеччина, Великобританія, Франція, Іспанія, Канада, роки патентування, джерела інформації. Патентний пошук проводився за такими напрямами: структура ЦВЗ, програмне забезпечення для створення ЦВЗ, програмне забезпечення і обладнання для ідентифікації ЦВЗ, технологія нанесення ЦВЗ на фотографію, способи видалення ЦВЗ з фотографії. По даному запиту було знайдено 74 патенти. Визначено таке співвідношення знайдених патентів відповідно до тематики пошуку:

- програмне забезпечення і обладнання для нанесення та ідентифікації ЦВЗ - 63,6 \%;

- технологія нанесення ЦВЗ на фотографію - 19,4 \%;
- способи видалення ЦВЗ 3 фотографії - 12,8 \%;

- структура ЦВЗ - 4,2 \%.

Наявність великої кількості патентів свідчить про стабільний розвиток даного напряму для захисту цифрового фото. Також спостерігається стала тенденція до зростання кількості патентів за досліджуваною темою, що підтверджує її актуальність та необхідність такого захисту у сфері цифрової фотографії.

На підставі вивчення науково-технічних джерел, патентів та інших інформаційних джерел, використаних в даній роботі, встановлено три головні методики створення цифрових водяних знаків для захисту цифрової фотографії: наукова цифрова стеганографія [5], цифрові водяні знаки [6] та цифровий підпис автора [7], які забезпечують надійний захист від фальсифікації та підміни авторства і надають можливість працювати 3 нею в будь-якому програмному та апаратному забезпеченні.

Запропоновано новий варіант захисту цифрового фото на початковій стадії його створення, який полягає в тому, щоб з самого початку у цифрову фотокамеру був вмонтований спеціальний пристрій для нанесення індивідуальної непомітної мітки з надто складною технологією іiі створення та неможливістю відтворення будь-яким способом.

На думку авторів, доречно було б з самого початку проектування фотоапарату закладати в нього ексклюзивну технологію нанесення на фото спеціальної мітки. 
Мова не йде про марку та модель фотокамери або поточної дати зйомки. Припустимо, при придбанні фотокамери купуватиметься не лише безпосередньо техніка, а й право бути власником тієї спеціальної мітки, яка відразу буде автоматично накладатись на зображення, як тільки воно буде створено. При цьому така мітка буде єдиною в світі і підробити її буде нереально, так саме, як і видалити, змінити її. До того ж ця мітка буде дублюватися при кожному копіюванні кадру.

Будь-хто, хто захоче придбати цифрове фото, або його «поцупити», має змиритися з тим, що автором на віки залишиться тільки власник мітки, що дозволить ефективно здійснювати захист авторських прав.

Спеціальна мітка - це не обов'язково має бути комбінація цифр, букв або логічне зображення, це можуть бути спеціальні хвилі, лінійні растри, хаотичні елементи дуже малих розмірів типу конфетті в паперовій масі, які застосовуються для захисту цінних паперів, та навіть надскладні ієрогліфи, головне - в цифровому вигляді і на досить складному рівні створення. Можна також використовувати кольорову градацію мітки при світлі або реакцію на УФ чи 14 промені.

Основною вимогою $є$ те, що ця мітка видима лише в електронному вигляді (спотворювати саме зображення вона не буде, вона майже прозора і побачити неозброєним оком іiї буде неможливо), тобто побачити її можна лише на комп'ютері або іншому обладнанні для зчитування зображення. При друці фото її видно не буде. Але ж оригіналом у цифровій фотографії вважається не надрукована фотографія, а її цифрова версія в електронному вигляді, тому довести своє авторство буде вельми просто.

При виконанні досліджень для реалізації запропонованого варіанту захисту цифрового фото було розроблено поопераційний алгоритм створення ЦВЗ для захисту цифрової фотографії, вигляд якого наведено на рис.

Як видно з рис., розроблений алгоритм дає можливість автору самостійно задавати складність ЦВЗ, його кольорові характеристики, координати розташування на фотографії тощо. Також за бажанням автора ЦВЗ можна зробити різним (індивідуальним) для кожної $з$ фотографій або для різних її замовників.

\section{Висновки}

В результаті проведених аналітичних досліджень можна стверджувати, що захист цифрової фотографії стоїть на переламному етапі свого розвитку і стрімко рухається вперед, і це пов'язано, насамперед, з бурхливим вдосконаленням фотографічної техніки та її функціональних можливостей.

На основі узагальнень в роботі запропоновано перспективний новий варіант захисту цифрової фотографії на початковій стадії її створення, розроблено поопераційний алгоритм створення спеціальної мітки (ЦВЗ), що здатний забезпечити ефективний захист авторських прав. 

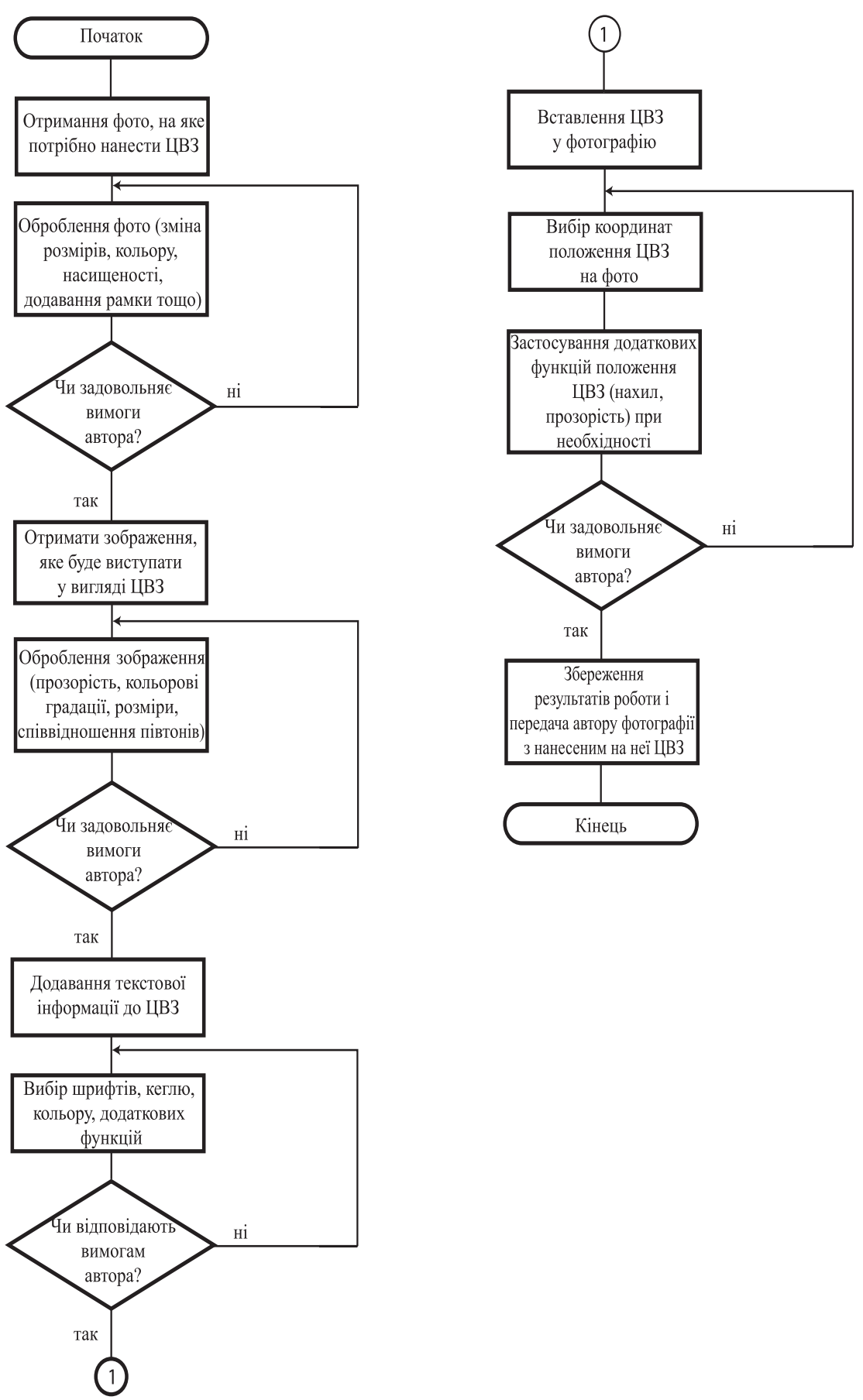

Поопераційний алгоритм створення ЦВЗ для захисту цифрової фотографії 
1. Андреев О. Недолугості фотопопулярності. Але все не так безнадійно [Електронний ресурс від 3 лютого 2009 р.] / Олег Андреев. - Режим доступу : http://www.consolieri.com.ua/usl4.html. 2. Хорошко В. О. Основи комп'ютерної стеганографії. Навчальний посібник / В. О. Хорошко, О. Д. Азаров, М. Є. Шелест, Ю. Є. Яремчук. - Вінниця : ВДтУ, 2003. - 143 с. З. Воробьев В. И. Цифровая стеганография / В. И. Воробьев, В. Г. Грибунин. - СПб. : ВУС, 2002. - 132 с. 4. Конахович Г. Ф. Компьютерная стеганография. Теория и практика / Г. Ф. Конахович, А. Ю. Пузыренко. - К. : «МК-Пресс», 2006. - 288 с. 5. Генне О. В. Основные положения стеганографии / О. В. Генне // Защита информации. Конфидент. - 2000. - № 3. 6. Добринина Н. Наложение цифровых водяных знаков на фотографию [Електронний ресурс від 25 травня 2009 р.] / Надежда Добринина. - Режим доступу : http://pepeh.org.ua/2009/04/12/page/3/. 7. Горький А. Новий етап захисту документації: електронний цифровий підпис. Його переваги та недоліки [Електронний ресурс від 8 жовтня 2009 р.] / Алексей Горький. Режим доступу : http://office.microsoft. com/ukua/excel/HA100997681058. aspx?pid $=\mathrm{CH} 101768401058$. 